\title{
ANALYSIS OF THE DIFFERENCES GIVEN BY THE PRESENCE / ABSENCE OF PERIPHERAL MANIFESTATIONS OF ANKYLOSING SPONDYLITIS
}

\author{
Sandra Burtică ${ }^{1}$, Antoaneta Drăgoescu ${ }^{2,3}$, Adriana Gurghean ${ }^{3,4}$ \\ ${ }^{1}$ National Institute of Rehabilitation, Physical Medicine and Balneoclimatology, Department of \\ Physical Medicine and Rehabilitation, Bucharest \\ ${ }^{2}$ National Institute of Public Health, Bucharest \\ ${ }^{3}$ Carol Davila University of Medicine and Pharmacy, Bucharest \\ ${ }^{4}$ Coltea Clinical Hospital, Department of Cardiology, Bucharest \\ Corresponding author: Sandra Burtică \\ sandra.burtica@gmail.com
}

\begin{abstract}
Objectives.Our study aimed to compare to what extent the characteristics of patients with ankylosing spondylitis (AS) differ, depending on the presence / absence of peripheral manifestations of the disease.
\end{abstract}

Materials and method. We analyzed a batch of 124 patients admitted to the rheumatology clinics of two hospitals, with ankylosing spondylitis according to the modified New York criteria. All individual patient characteristics were documented from patient observation sheets. We divided the population into two groups: the $P+$ group representing the patients with peripheral manifestations of arthritis or enthesitis $(N=56)$ and the $P$-group representing the patients without the peripheral manifestations $(N=68)$. Statistical processing was performed using IBM SPSS and Microsoft Excel.

Results. In the subtype of patients $P+$ the mean age was 45.1414 .16 years, and in the subtype $P$ - mean age was 43.84 years 12.58 years. Gender distribution of patients in the two subgroups shows higher frequencies for patients without peripheral manifestations $P$ - in both genders, respectively 55.4\% in males and 52.2\% in females. The highest frequencies were registered at the normal BMI of 18.5-24.9 in both sublots, respectively $51.8 \%$ for the $P+$ patients and $45.6 \%$ for the $P$ - patients. The degree of activity of the disease, based on the ASDAS -CRP score, within both $P+$ and $P$ - subgroups, revealed a majority of patients with inactive disease $(\leq 1.3)$. Within the $P+$ and $P$ - sublots, most patients had the BASDAl index in the range $0-0.9$, that is $67.9 \%$ of the patients in the $P+$ sublot and $64.7 \%$ of those in the $P$ - sublot, respectively. This shows that the majority of patients in both subgroups had a good therapeutic response to biological treatment, with symptoms such as pain and / or fatigue absent or very low in intensity.

There were no statistically significant differences between the two subgroups. 


\section{INTERNAL}

\section{Original papers}

Conclusion. Even though there were no major paraclinical differences between the patients with pure axial ankylosing spondylitis and patients with AS with peripheral manifestations, the patients with peripheral manifestations of the disease should be approached by a multidisciplinary team.

Keywords: ankylosing spondylitis; axial disease; peripheral manifestations; BASDAI.

\section{Rezumat}

Obiective. Studiul nostru a urmărit să compare în ce măsură diferă caracteristicile pacienților cu spondilită anchilozantă (SA), în funcție de prezența / absența manifestărilor periferice ale bolii.

Material și metodă. Am analizat un lot de 124 de pacienți internați în clinicile de reumatologie din două spitale, cu spondilită anchilozantă în conformitate cu criteriile modificate din New York. Toate caracteristicile individuale ale pacientului au fost documentate din fișele de observație. Am împărțit populația în două grupuri: grupul P+ reprezentând pacienții cu manifestări periferice de artrită sau entezită $(N=56)$ și grupul $P$ - reprezentând pacienții fără manifestări periferice $(N=$ 68). Prelucrarea statistică a fost efectuată folosind IBM SPSS și Microsoft Excel.

Rezultate. În subtipul pacienților $P$ + vârsta medie a fost de 45,1414,16 ani, iar în subtipul Pvârsta medie a fost de 43,84 ani12,58 ani. Distribuția de gen a pacienților din cele două subgrupuri arată frecvențe mai mari pentru pacienții fără manifestări periferice $P$ - la ambele sexe, respectiv 55,4\% la bărbați și 52,2\% la femei. Frecvențele cele mai ridicate au fost înregistrate la IMC normal de 18,5-24,9 în ambele subloturi, respectiv 51,8\% pentru pacienții P+ și 45,6\% pentru pacienții P-. Gradul de activitate al bolii, bazat pe scorul ASDAS - CRP, în cadrul subgrupurilor $P+$ și $P_{-}$, a relevat majoritatea pacienților $\mathrm{Cu}$ boală inactivă $(\leq 1,3)$. În cadrul subloturilor $P+$ și P-, majoritatea pacienților au avut indicele BASDAl în intervalul 0-0,9, adică $67,9 \%$ dintre pacienții din sublotul $P+$, respectiv 64,7\% dintre cei din sublotul $P$-. Acest lucru arată că majoritatea pacienților din ambele subgrupuri au avut un răspuns terapeutic bun la tratamentul biologic, cu simptome precum durere și / sau oboseală absentă sau intensitate foarte mică. Nu au existat diferențe semnificative statistic între cele două subgrupuri.

Concluzii. Chiar dacă nu au existat diferențe paraclinice majore între pacienții cu spondilită anchilozantă forma axială pură și pacienții cu SA având și manifestări periferice, pacienții cu manifestări periferice ale bolii trebuie abordați de o echipă multidisciplinară.

Cuvinte cheie: spondilită anchilozantă; boală axială; manifestări periferice; BASDAI. 


\section{Introduction}

Historical evidence of ankylosing spondylitis has been known for almost 5,000 years, when skeletons were found in ancient Egypt, with changes typical of this disease in the spine, namely the "bamboo spine", as well as multiple osteophytes ${ }^{(1)}$. Ankylosing spondylitis is a complex systemic, chronic and autoimmune disease, which mainly affects the axial skeleton and has an uncertain etiology ${ }^{(2)}$. Its main feature is represented by the inflammatory lower back pain, which is due to sacroilitis and spondylitis, being frequently associated with enthesitis, peripheral arthritis, as well as with anterior uveitis ${ }^{(3)}$.

Ankylosing spondylitis is a disease with unpredictable evolution, which does not have the same pattern in all patients ${ }^{(4)}$, although the literature suggests a possible correlation of symptoms in the first ten years of the disease ${ }^{(5)}$.

Spondyloarthropathies represent a group of inflammatory arthritis, which include ankylosing spondylitis and peripheral arthritis consisting of psoriatic arthritis / spondylitis, arthritis / spondylitis associated with inflammatory bowel disease, reactive arthritis (Reiter's syndrome), as well as undifferentiated arthritis ${ }^{(6)}$. According to ASAS (Assessment of SpondyloArthritis International Society), spondyloarthritis can be classified according to the predominant symptoms - axial or peripheral - and according to the presence / absence of other associated pathologies (psoriasis / inflammatory bowel disease / infection) ${ }^{(7)}$. As a result, there are classification sets that combine multiple signs, symptoms, genetic factors, etiological agents or paraclinical investigations, with high specificity. Probably the most important symptom in spondyloarthropathy is the inflammatory lumbar pain, which denotes inflammation of the sacroiliac joints, spine, and entheses, but with sensitivity and specificity in relation to the diagnosis of ankylosing spondylitis of only $80 \%{ }^{(8)}$.

Thus, spondyloarthropathies can be differentiated on the basis of the presence / absence of HLA-B27 antigen, of the characteristics that define peripheral arthritis (asymmetry, oligoarticular, predominantly in the lower limbs), as well as the possible association of sacroilitis, spondylitis, dactylitis, enthesitis or anterior uveitis $^{(9)}$.

Seronegative spondyloarthritis may include ankylosing spondylitis, as well as juvenile spondyloarthritis, reactive arthritis, psoriatic arthritis, enteropathic spondyloarthritis (associated with inflammatory bowel disease - Crohn's disease and ulcer-haemorrhagic rectocolitis), as well as non-diarrheal spondyloarthritis ${ }^{(4)}$.

\section{Objectives}

Our study aimed to compare to what extent the characteristics of patients with ankylosing spondylitis differ, depending on the presence / absence of peripheral manifestations of the disease.

\section{Materials and methods}

We analyzed a batch of 124 patients admitted to the rheumatology clinics of two hospitals, with ankylosing spondylitis according to the modified New York criteria. All individual patient characteristics were documented from patient observation sheets, both demographic and disease duration, type of joint involvement, BASDAI score, mini-BASDAl score, impairment 


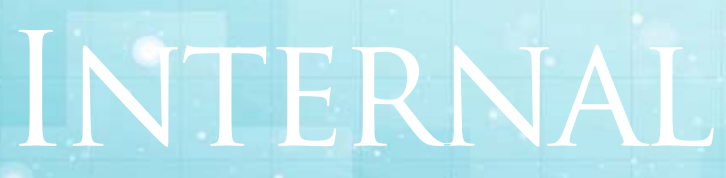

Original papers

functional indices of spine mobility, activity score of "Assess Disease Activity in Ankylosing Spondylitis" correlated with Creactive protein (ASDAS-CRP), as well as markers of inflammation in the blood (ESR and CRP).

We divided the population into two groups: the $P+$ group representing the patients with peripheral manifestations of arthritis or enthesitis ( $N=56$ ) and the P-group representing the patients without the peripheral manifestations $(\mathrm{N}=68)$. Statistical processing was performed using IBM SPSS and Microsoft Excel.

\section{Results}

The distribution of patients from the two subgroups, according to age, shows in the $\mathrm{P}+$ sublot the highest frequency of 9 patients in the age group 45-49 years. In the P-sublot, the highest frequency of 13 patients was recorded in the age group 35-39 years. In the subtype of patients $\mathrm{P}+$ the mean age was 45.1414.16 years, and in the subtype $P$ mean age was 43.84 years 12.58 years.

Gender distribution of patients in the two subgroups shows higher frequencies for patients without peripheral manifestations Pin both genders, respectively $55.4 \%$ in males and $52.2 \%$ in females.

In the $\mathrm{P}+$ sublot, the average height of the patients was $174.80 \mathrm{~cm} 8.09 \mathrm{~cm}$, with a minimum of $160 \mathrm{~cm}$ and a maximum of 195 $\mathrm{cm}$. In the subset of patients $\mathrm{P}$ - the average height was $173.88 \mathrm{~cm} 8.80 \mathrm{~cm}$, with a minimum height of $157 \mathrm{~cm}$ and a maximum height of $195 \mathrm{~cm}$.

Regarding weight, in the subtype of patients $\mathrm{P}+$ the highest frequency was at the weight of $71-80 \mathrm{~kg}$, respectively 17 patients.

In the P-sublot, the increased frequency was registered at $71-80 \mathrm{~kg}$, respectively 26 patients. The highest frequencies were registered at the normal $\mathrm{BMI}$ of 18.5-24.9 in both sublots, respectively $51.8 \%$ for the $\mathrm{P}+$ patients and $45.6 \%$ for the P-patients.

Regarding the status of smoker / nonsmoker, the proportion of non-smokers was $85.7 \%$ among patients with peripheral manifestations and $79.4 \%$ among those without peripheral manifestations.

Regarding the time interval between the time of disease onset and diagnosis, in the case of subtype $\mathrm{P}$-, most cases, respectively $39.7 \%$, were diagnosed within 1 year from the time of disease onset, while the least cases, respectively $1.5 \%$, were diagnosed every 4 or 8 years.

In the case of the $\mathrm{P}+$ sublot, most patients, respectively $35.7 \%$, were diagnosed earlier than the patients in the other sublot, namely in the same year with the onset of the first symptoms of the disease, while the few in the sublot, respectively $1,8 \%$, were diagnosed 8 years after the onset of the first symptoms. 
In the case of subtype P-, most patients, respectively $39.7 \%$, were under treatment with adalimumab at enrollment in the study. In the case of the $\mathrm{P}+$ subgroup, most patients, respectively $33.9 \%$, were under treatment with adalimumab, to the same extent as those under treatment with etanercept, respectively $33.9 \%$.

The fewest patients, in both subgroups, were undergoing treatment with secukinumab, respectively $1.5 \%$ for patients without peripheral manifestations and $3.6 \%$ for those with peripheral manifestations.

The other patients in subtype P- were under treatment with the following: etanercept (30.9\%), infliximab (23.5\%), golimumab $(4.4 \%)$. In the case of the P+ sublot, the other patients were at the time of enrollment in the study, in treatment with: infliximab (23.2\%) or golimumab (5.4\%).

Regarding the distribution of the subgroups according to the number of years since the initiation of the treatment, in the subgroup Pmost patients, respectively 11 , were initiated 7 years after enrolling in the study, whereas in the subgroup $\mathrm{P}+$ most patients, respectively 10 , had begun biological treatment 9 years ago (Figure 1 ).

In the patients of the two subgroups, the highest frequency is registered by the patients who use nonsteroidal antiinflammatory drugs when needed, that is $85.7 \%$ patients in the $\mathrm{P}+$ sublot, respectively $73.5 \%$ patients in the $P$ - sublot.

A total of 48 patients in the $\mathrm{P}+$ subgroup used NSAIDs, while 8 patients did not use any nonsteroidal anti-inflammatory drugs. Also, in the case of subtype $\mathrm{P}_{-}, 50$ patients from subtype P- used NSAIDs, while 18 did not use NSAIDs.

Within the $\mathrm{P}+$ and $\mathrm{P}$ - sublots, most patients had the BASDAI index in the range $0-0.9$, that is $67.9 \%$ of the patients in the P+ sublot and
$64.7 \%$ of those in the P- sublot, respectively. This shows that the majority of patients in both subgroups had a good therapeutic response to biological treatment, with symptoms such as pain and / or fatigue absent or very low in intensity (Figure 2 ).

There was no statistically significant difference between the two subgroups, with $p=0.5419$ (Kruskal-Wallis test).

Within the two subgroups of the study, the mini-BASDAI values were comparable. Thus, at the level of the $\mathrm{P}+$ subgroup, most patients, in this case $62.5 \%$, had minimum mini-BASDAl values, ranging from $0-0.9$, as well as those in the P- subgroup, where the highest proportion of patients (50\%) had values within the same range. (Figure 3.) There was also no statistically significant difference between the two subgroups, with $p=0.2145$ (Kruskal-Wallis test).

Regarding the markers of inflammation, represented in our study by ESR and CRP, the majority of patients in both subgroups had normal values of both parameters.

Thus, a proportion of $79.4 \%$ of patients in the $P$ + subtype and a proportion of $71.4 \%$ of patients in the P- subtype had normal ESR values $(<20 \mathrm{~mm} / \mathrm{h})$, whereas only $28.6 \%$ between patients with peripheral manifestations and, respectively, $20.6 \%$ of patients without peripheral manifestations, had higher values of ESR ( $>20 \mathrm{~mm} / \mathrm{h}$ ) (Figure 4).

Regarding CRP, as in the case of ESR, most patients, from both subgroups, had normal values. Thus, $62.5 \%$ of patients in the subtype with peripheral manifestations and, respectively, $61.8 \%$ of patients in the sublot without peripheral manifestations, had normal CRP values ( $<5 \mathrm{mg} / \mathrm{l}$ ) (Figure 5 ).

The Schober index within the two subgroups had values $<5 \mathrm{~cm}$, revealing, as expected, as in the case of the total group, a limitation of the mobility of the thoraco-lumbar spine. 


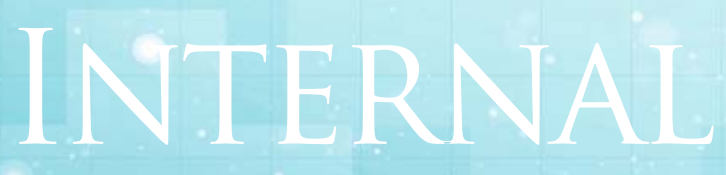

Original papers

The lateral flexion index within the two sublots showed a majority of patients with normal values $(>10 \mathrm{~cm})$. Thus, a proportion of $89.3 \%$ of patients in the $\mathrm{P}+$ sublot and $83.3 \%$ of those in the P- sublot, respectively, showed a normal lateral flexion of the dorsallumbar spine, with values over $10 \mathrm{~cm}$.

The occiput - wall index within the two subgroups studied had normal values $(0 \mathrm{~cm})$. Thus, in the patients with peripheral manifestations, $57.1 \%$ of them had normal values of the occiput index - wall, while $42.9 \%$ had high values, thus revealing a deficient extension of the cervical spine, due to the physiopathological changes induced of ankylosing spondylitis.

The chin - sternum index in flexion, within the two subgroups $\mathrm{P}+$ and $\mathrm{P}-$, revealed a majority of the patients in the sublot with peripheral manifestations having increased index values $(>0 \mathrm{~cm})$, which shows that the flexion of the cervical spine is affected, as a result of the evolution of ankylosing spondylitis, whereas in the case of the sublot of patients without peripheral manifestations, the majority of patients presented normal values of the chin - sternum index in flexion.

Also, the index finger - soil within the two subgroups had increased values $(>0 \mathrm{~cm})$, which indicates the limitation of the flexion of the dorsal-lumbar spine.

The degree of activity of the disease, based on the ASDAS - CRP score, within both P + and
P-subgroups, revealed a majority of patients with inactive disease ( $\leq 1.3)$.

\section{Discussions}

In our study of 124 patients with ankylosing spondylitis, a number of 56 patients also presented peripheral manifestations, while 68 patients did not have any symptoms of peripheral disease. These symptoms are represented by peripheral arthritis, enteritis, dactylitis and/or extra-articular disease (inflammatory bowel disease, uveitis, psoriasis).

Comparing the sublots, both in the sublot of patients with peripheral manifestations $(\mathrm{P}+)$ and in the sublot of patients without peripheral manifestations ( $P$-), the highest frequency of patients was registered in the age group 35-39 years. The mean age in the $P$ + subgroup was 45.1414 .16 years, while in the $\mathrm{P}$ - subgroup it was 43.8412 .58 years, with no statistically significant differences between the two subgroups ( $p=0.48$; Kruskal-Wallis test). Similar results were also obtained by de Winter et al., who found the mean age for patients $P+41$ years (33-52 years) and 48 years (37-56 years) for patients $\mathrm{P}_{-}{ }^{(10)}$.

Regarding gender distribution, in our study, higher frequencies were shown for $\mathrm{P}$ patients in both genders, respectively $55.4 \%$ in men and $52.2 \%$ in women. Thus, we can to 


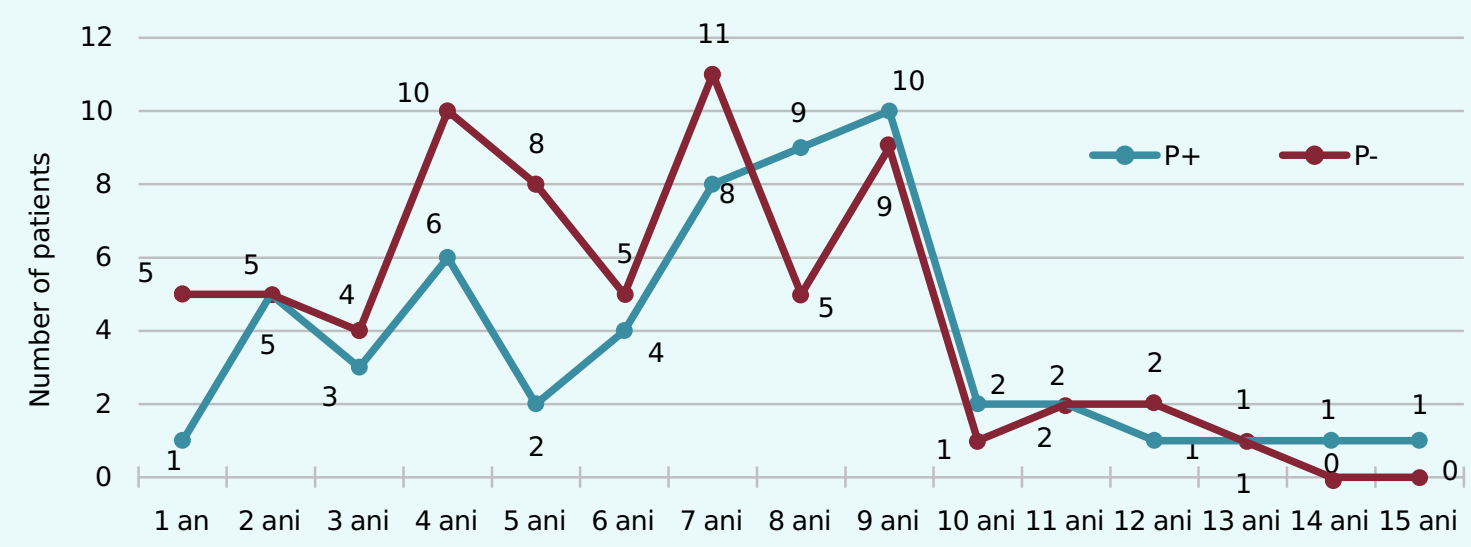

Figure 1. Subgroup distribution according to the number of years since the initiation of biological treatment

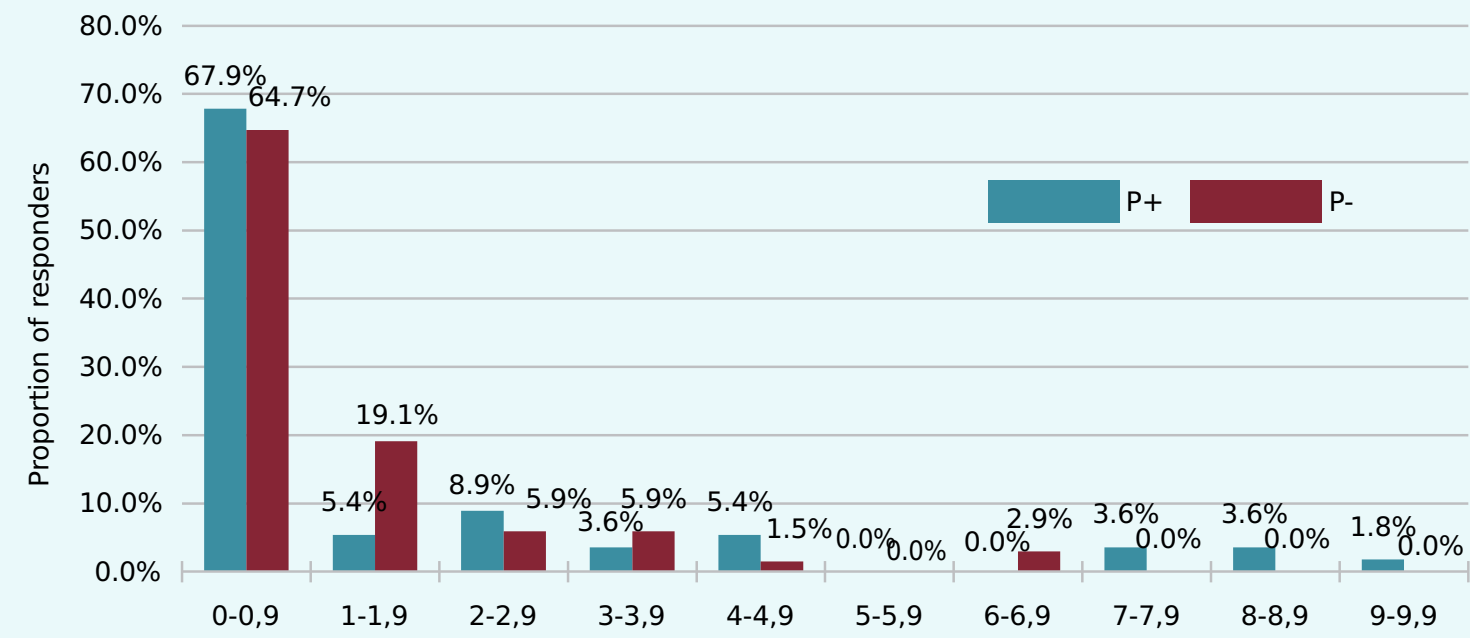

Figure 2. BASDAl index in the two sublots

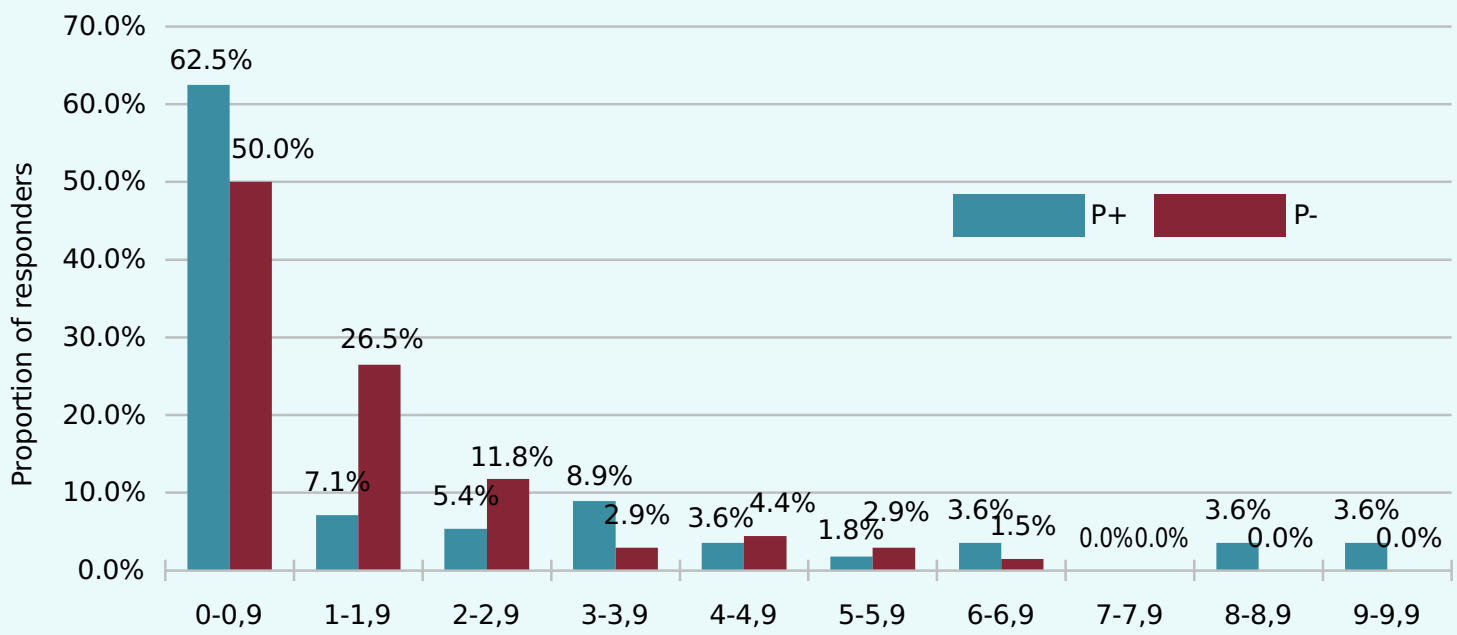

Figure 3. Mini-BASDAl index in the two sublots 


\section{INTERNAL}

\section{Original papers}

some extent conclude that gender affects both women and men alike, in the case of patients without peripheral disease manifestations. However, this is difficult to say, given the limited number of women in the study group.

Neither height nor weight played any role in affecting patients with AS depending on the presence / absence of peripheral manifestations, with $p$ without statistical significance. The good therapeutic response of patients from both subgroups ( $P+$ and $P$-) was first quantified by the BASDAl index, which was included in most patients in the range 0-0.9, which indicates the absence or very low intensity of the represented symptoms through pain and / or fatigue. Thus, over $90 \%$ of the patients had mild disease, with a BASDAI index between 0-4.9. There were no statistically significant differences between the two subgroups.

Since the mini-BASDAl index is not sufficiently used in current practice, we decided to analyze it in relation to the BASDAI index. Thus, the results obtained were the same as in the case of the BASDAl index, with a majority of patients with mild impairment in both subgroups, the only difference being that, in the case of the mini-BASDAl index, there were also small percentages of patients with medium impairment, whereas in the BASDAI index there were no patients with average disease. There were also statistically significant differences between the patients in the two subgroups, with severe disease dependence according to the mini-BASDAl index, where $p=0.03$ (KruskalWallis test).

Also, in our analysis, the markers of inflammation (ESR and CRP) had normal values in the majority of patients, both from the subgroup of patients with peripheral manifestations and from the subgroup of those without.

\section{Conclusions}

Following our study, there were no major differences of the paraclinical parameters between the patients with pure axial ankylosing spondylitis and the patients with ankylosing spondylitis associated with peripheral manifestations of the disease. The indicators of flexibility of the spine were also quite similar in both categories of patients. However, due to the fact that they experience more symptoms in various areas of the body, the patients with peripheral manifestations of the disease should be approached by a multidisciplinary team.

\section{Bibliography}

1. Bywaters, E., 1979. Historical aspects of ankylosing spondylitis. Rheumatol Rehabil. 1979;18(4): 197-203.

2. Edavalath M. Ankylosing spondylitis. J Ayurveda Integr Med. 2010;1(3):211-214. doi:10.4103/09759476.72619 


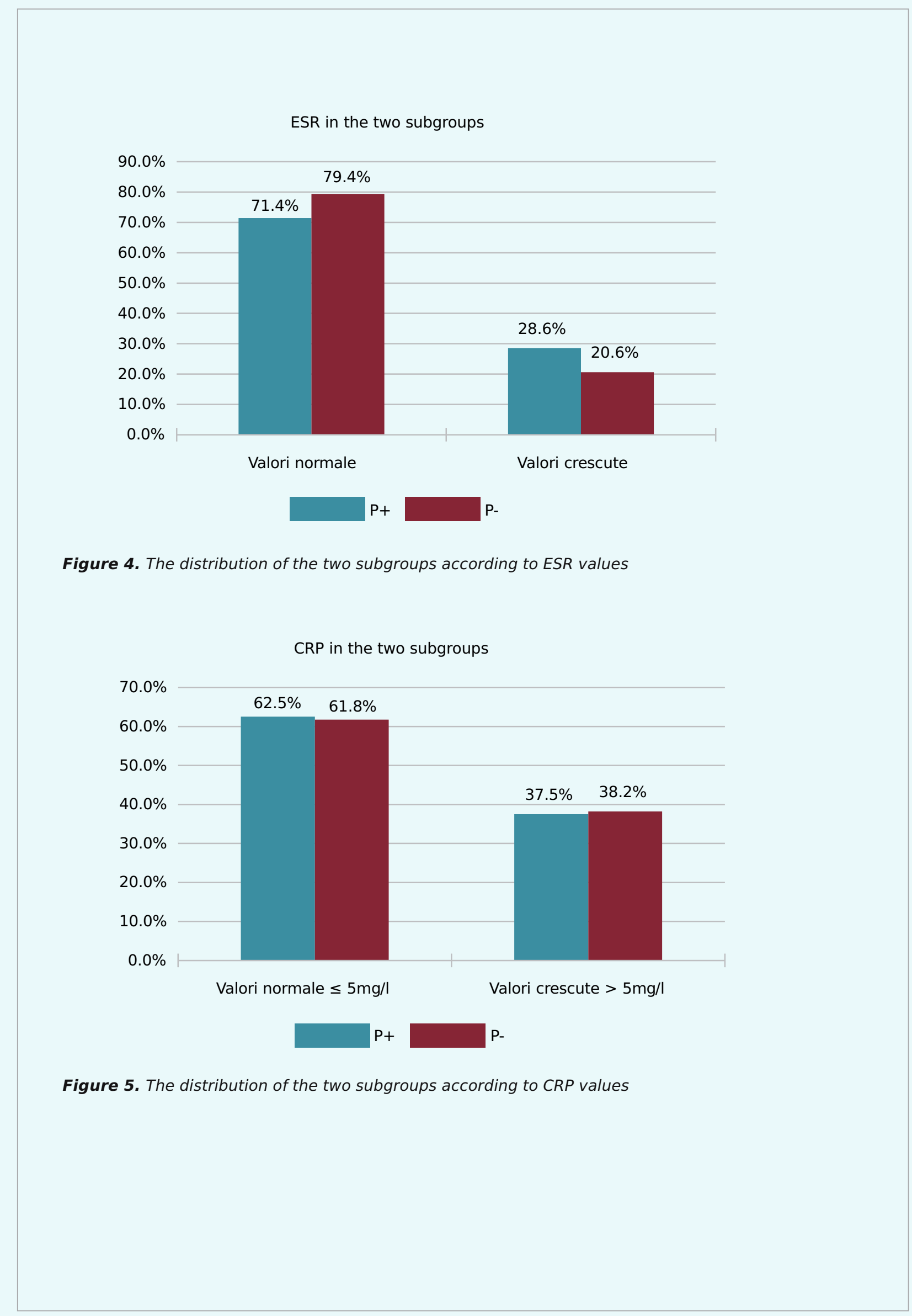




\section{INTERNAI}

Original papers

3. Zochling J, van der Heijde D, Burgos-Vargas $R$, et al. ASAS/EULAR recommendations for the management of ankylosing spondylitis. Ann Rheum Dis. 2006;65(4):442-452. doi:10.1136/ard.2005.041137

4. Sieper J, Braun J, Rudwaleit M, Boonen A, Zink A. Ankylosing spondylitis: an overview. Ann Rheum Dis. 2002;61 Suppl 3(Suppl 3):iii8-iii18. doi:10.1136/ ard.61.suppl_3.iii8

5. Carette, S. , Graham, D. , Little, H. , Rubenstein, J. and Rosen, P. (1983), The natural disease course of ankylosing spondylitis. Arthritis \& Rheumatism, 26: 186190. doi:10.1002/art.1780260210

6. Akgul O, Ozgocmen S. Classification criteria for spondyloarthropathies. World J Orthop. 2011;2(12):107-115. doi:10.5312/wjo.v2.i12.07

7. Rudwaleit $M$, van der Heijde $D$, Landewé $R$, et al. The development of Assessment of SpondyloArthritis international Society classification criteria for axial spondyloarthritis (part II): validation and final selection. Annals of the Rheumatic Diseases 2009;68:777-783.

8. Sieper J, van der Heijde D, Landewé $R$, et al. New criteria for inflammatory back pain in patients with chronic back pain: a real patient exercise by experts from the Assessment of SpondyloArthritis international Society (ASAS). Annals of the Rheumatic Diseases 2009;68:784-788.

9. Lipton S, Deodhar A, 2012. The New ASAS Classification Criteria for Axial and Peripheral Spondyloarthritis. Int J Clin Rheumatol, pp. 7(6):675682.

10. de Winter JJ, Paramarta JE, de Jong HM, et al. Peripheral disease contributes significantly to the level of disease activity in axial spondyloarthritis. RMD Open. 2019;5:e000802. doi: 10.1136/rmdopen-2018-000802 